\begin{tabular}{c} 
TẠP CHÍ KHOA HỌC ĐẠI HỌC TÂN TRÀO \\
ISSN: 2354 - 1431 \\
\hline
\end{tabular}

\title{
Diễn ngôn giới thứ hai thể hiện qua một số truyện ngắn tiêu biểu của nhà văn Y Ban
}

\author{
Truong Thị Thu Thanh ${ }^{a^{*}}$ \\ ${ }^{a}$ Truò̀ng Đại học Phú Yên \\ *Email:truongthuthanhdhpy@gmail.com
}

\section{Thông tin bài viết}

Ngày nhận bài:

21/10/2018

Ngày duyệt đăng:

10/12/2019

Tù khóa:

Y Ban; Giới nũ்; Lý thuyết diễn ngôn; Phân tâm học;

Triết học hiện sinh.

\section{Tóm tắt}

Hình ảnh về những người phụ nữ với đủ mọi tầng lớp, gắn với nhiều cuộc đời khác nhau, không phải là mới trong văn học Việt Nam; nhưng đi sâu khám phá những vấn đề liên quan đến nữ giới dưới góc độ diễn ngôn là hướng đi mới trong nghiên cứu văn học. Trong bài viết này, chúng tôi tập trung khai thác một số truyện ngắn tiêu biểu của $\mathrm{Y}$ Ban viết về những người phụ nữ luôn có khát khao được hạnh phúc, khát khao được yêu thương, khát khao được thoả mãn những nhu cầu bản năng đời thường của con người. Ở họ luôn là một cuộc hành trình đi tìm bản thể, và để từ đó, khi thấy được tầm quan trọng bản thể nữ giới, họ cố gắng vươn lên để khẳng định nhân vị đàn bà, khẳng định quyền bình đẳng giới của mình.

\section{1. Đặt vấn đề}

Vào năm 1949, công trình Giới thú hai của Simone de Beauvoir ra mắt công chúng bạn đọc như tiếng nói góp phần chứng minh thực trạng phụ nữ yếu kém hơn đàn ông là do toàn bộ những điều kiện kinh tế, ý thức xã hội, hệ tư tưởng, văn hoá, giáo dục quy định trong tiến trình phát triển lịch sử. Vấn đề nữ quyền rầm rộ ở cả Phương Đông và Phương Tây. Tiếp nối công trình Giới thú hai của Simone de Beauvoir là những công trình như: The New Feminist Criticism (Lý thuyết phê bình nữ quyền mới) của Elaine Showalter, Contemporary Literary Criticism (Phê bình văn học hiện đại) của Robert Con Davis,... Ở Trung Quốc, các nhà văn nữ Vệ Tuệ, Thiết Ngưng, Miên Miên cũng nổi lên đình đám trên văn đàn. Còn ở Việt Nam thì có $\mathrm{Y}$ Ban, Nguyễn Ngọc Tư, Đỗ Hoàng Diệu, Trần Thùy Mai, Nguyễn Thị Thu Huệ, Phạm Thị Hoài,... cũng thu hút độc giả. Nhiều bài viết nghiên cứu văn học xuất hiện như: Nguyễn Huy Thiệp với Tính dục trong văn hoc hôm nay, Vương Trí Nhàn với Văn hoc sex: chấp nhận để tìm cách đổi khác, Nguyễn Đăng Điệp với Vấn đề phái tính và âm huởng nũ quyền trong văn học Việt
Nam đương đại, Trương Thị Thu Thanh với Ngôn ngũ thân thể trong truyện ngắn của một số nhà văn nũ Việt Nam đương đại,...Còn về việc vận dụng lý thuyết diễn ngôn vào nghiên cứu văn học cũng không kém phần phong phú. Các nghiên cứu như: Trần thuật học nhu là khoa học phân tích diến ngôn trần thuật của V.I. Chiupa, (Lã Nguyên dịch), Trò chơi diễn ngôn trong lý thuyết văn học hậu hiện đại của Trần Ngọc Hiếu, Nhũng hình thái diễn ngôn mới trong tiểu thuyết lịch sủ Việt Nam sau đổi mới của Nguyễn Văn Hùng, Bản chất xã hội, thẩm mĩ của diễn ngôn văn học của Trần Đình Sử, Diễn ngôn giới nũ trong truyện ngắn Bóng đè (Đố Hoàng Diệu) và trong truyện ngắn Điên cuồng nhu Vẹ Tuệ (Vệ Tuệ) của Tạ Thị Nhanh,... Như vậy, có thể nói bình đẳng giới được xem là vấn đề riết róng ở thế giới và cả Việt Nam. Đặc biệt, sau công cuộc đổi mới toàn diện đất nước năm 1986, nhiều phong trào văn học nữ xuất hiện và phát triển về mặt số lượng lẫn chất lượng. Họ góp thêm tiếng nói của mình để bộc bạch những khát khao chung của phụ nữ. Họ đứng về "giới thứ hai" để bảo vệ và đòi quyền bình đẳng giới. Với sự mong muốn tìm hiểu những nét độc đáo, đặc trưng của "lối 
viết nữ" và khát khao khám phá những chiều sâu bản ngã con người qua những sáng tác của $Y$ Ban trên tinh thần hướng đến những giá trị nhân sinh và thẩm mỹ bằng lý thuyết diễn ngôn, chúng tôi quyết định lựa chọn đề tài Diễn ngôn giới thứ hai thể hiện qua một số truyện ngắn tiêu biểu của nhà văn Y Ban. Bài viết hướng về bình diện nhân vật người phụ nữ với tâm thế hiện sinh và sự khẳng định bản thể nữ. Việc tìm hiểu đề tài Diễn ngôn giới thư hai thể hiện qua một số truyện ngắn tiêu biểu của nhà văn $Y$ Ban bước đầu hệ thống hóa và lý giải cơ bản những vấn đề lý luận về nữ quyền và lý thuyết diễn ngôn trong văn học đương đại nói chung và truyện ngắn $\mathrm{Y}$ Ban nói riêng. Đây là một hệ quả của tiến trình dân chủ hoá xã hội và văn học. Cấu trúc của bài viết gồm có các nội dung: Lý thuyết về diễn ngôn giới thứ hai, hành trình đi tìm bản thể nữ, khẳng định bản thể nữ, niềm kiêu hãnh nữ giới.

\section{Lý thuyết về diễn ngôn giới thứ hai}

Diễn ngôn là gì? Và diễn ngôn có tầm quan trọng như thế nào trong trong nghiên cứu văn học? Có rất nhiều quan điểm khác nhau về thuật ngữ diễn ngôn cũng như hướng nghiên cứu của từng trường phái văn học, trào lưu hay chủ nghĩa văn học hoặc các ngành khoa học.

Đối với nhà ngôn ngữ học cấu trúc De Sausure, diễn ngôn được đặt trong cấu trúc ngôn ngữ. Ngôn ngữ gồm cái biểu đạt và cái được biểu đạt. Cái biểu đạt gồm âm thanh, ngữ âm, từ, câu,...và cái được biểu đạt là ý nghĩa câu, tư tưởng, nội dung. Nhưng đối lập với quan điểm của các nhà ngôn ngữ học và chủ nghĩa hình thức thì $\mathrm{M}$. Bakhtin cho rằng cần nghiên cứu diễn ngôn trong mối tương quan với đời sống xã hội và ý thức hệ. Diễn ngôn là sự biểu đạt trên câu tồn tại trong đời sống thực tiễn. "Tất cả mọi đặc điểm của diễn ngôn mà tôi biết là tính kí hiệu thuần tuý, tính thích ứng phổ biến về ý thức hệ, tính tham dự giao tiếp đời sống" ${ }^{2}$. Còn đối với Foucault, diễn ngôn gắn với loại hình tri thức và quyền lực xã hội. Chính vì vậy, ngôn ngữ chính là phương thức biểu đạt của tư tưởng và lịch sử. Diễn ngôn phải gắn với sức mạnh của nhân văn và sức mạnh thực tiễn. Diễn ngôn là một chỉnh thể thống nhất giữa nội dung và hình thức, chỉnh thể trong cái chính thể của xã hội. “Thuật ngữ diễn ngôn có thể xác định là một chỉnh thể trần thuật hình thành hệ thống đồng nhất."”. Mặt khác,

\footnotetext{
${ }^{5}$ Bakhtin (1998), Bakhtin toàn tập, tập 2, Nxb Giáo dục Hà Bắc, Thạch Gia Trang; tr 357

${ }^{6}$ Foucault M (1998), Khảo cổ học tri thức, Nxb Tam Liên, Thượng Hải; tr 136
}

diễn ngôn là cách nói năng, phương thức biểu đạt về con người, thế giới, về các sự việc trong đời sống. Nghiên cứu diễn ngôn chính là nghiên cứu ngôn ngữ. Ngôn ngữ là tư duy của vỏ não con người. Nhưng điều đó không đồng nghĩa rằng diễn ngôn phải là công cụ diễn đạt mà là bản chất của tư tưởng, là biểu hiện của một ý thức hệ. Ngôn ngữ thể hiện tư tưởng, quan điểm, quyền lực, địa vị của con người trong mối tương quan với xã hội. Đối với nhà văn, diễn ngôn chính là biểu hiện tư tưởng nghệ thuật, là lập trường, là phong cách, là tài năng sử dụng ngôn ngữ,... Vì vậy, diễn ngôn là hiện tượng siêu văn bản, liên văn bản, liên văn hóa trong tính thống nhất, tính hệ thống, tính chỉnh thể. Một sự tụ họp, kiến tạo. Có nghĩa rằng, một từ ngữ trong tác phẩm văn học là sự tác động qua lại của tác giả - người đọc - nhân vật, sự kiện. Qua đó, chúng ta thấy, quan điểm của Foucault và của Bakhtin giống nhau ở chỗ nhấn mạnh tính thực tiễn của diễn ngôn. Ở góc độ khác, diễn ngôn theo tiếng Pháp là discourse, có nghĩa là lời nói, là phát ngôn, là hành động lời nói tạo sinh văn bản gồm người nghe bình đẳng với người nói”,7 quyền lực đa dạng trong cuộc sống. Diễn ngôn cũng là phương cách tạo lập nên tri thức cùng những thực hành xã hội, các dạng thức của chủ thể và mối quan hệ quyền lực. Còn theo Van Dijk cho rằng, từ giữa những năm 1980 , phân tích - diễn ngôn bước vào giai đoạn phát triển theo hướng chuyên môn hoá trong nội bộ chuyên ngành. Bắt đầu xuất hiện các lí thuyết diễn ngôn chuyên ngành, ví như lí thuyết diễn ngôn tư tưởng hệ, lí thuyết diễn ngôn dân tộc học, lí thuyết diễn ngôn của nhóm xã hội thiểu số, lí thuyết diễn ngôn của chủ nghĩa phân biệt chủng tộc... Một trong những khuynh hướng rộng lớn và nhiều cành nhánh nhất nghiên cứu về diễn ngôn chính là phân tích - diễn ngôn. Trong những năm cuối đời, bản thân Van Dijk cũng tập trung vào lĩnh vực nghiên cứu diễn ngôn. Tư tưởng hệ. J. Torfing khái quát, lí thuyết diễn ngôn xuất hiện như là sự gặp gỡ của các ngành khoa học ở ý đồ liên kết các quan điểm cốt lõi của ngôn ngữ học và thông diễn học với những tư tưởng then chốt của khoa học xã hội và khoa học chính trị. Ý đồ đó được khuyến khích bởi sự liên kết ngày càng chặt chẽ giữa ngôn ngữ học và chính trị học trong quá trình biến đổi xã hội. Còn nhìn ở góc độ phân tích diễn ngôn hậu cấu trúc luận thì chúng ta có thể tìm thấy ở những công trình của Roland Barthes, Julia Kristeva,

\footnotetext{
${ }^{7}$ V.I. Chiupa, Lã Nguyên dịch (2013), Trần thuật học nhu là khoa học phân tích diễn ngôn trần thuật, truy cập ngày 13/9/2013, http://www.hcmup.edu.vn/index.php?option=com content\&id=14838 \&tmpl=component\&task=preview\&lang=vi\&site=142; $\operatorname{tr} 60,61$
} 
Jacques Lacan. Trong đó, diễn ngôn được xem là tổng thể các thực tiễn xã hội mà mọi ý nghĩa và tư tưởng đều được kiến tạo và tái tạo trong khuôn khổ của nó. Quan niệm diễn ngôn của hậu cấu trúc luận tương đồng với khái niệm ngôn ngữ của Richard Rorty và khái niệm giao tiếp của Nicholas Luckmann. Nguồn mạch tri thức của lí thuyết diễn ngôn hậu trúc luận còn là những tư tưởng hậu marxiste của Louis Althusser và Antonio Gramsci. Theo Jorgensen và L. Phillips, diễn ngôn trước hết là hệ thống kí hiệu bao gồm những thành phần như ngôn ngữ và hình ảnh. Diễn ngôn không chỉ kiến tạo thế giới, mà bản thân nó cũng do thế giới kiến tạo nên. Hiện thực xã hội khách quan được xem là cấu trúc có ảnh hưởng tới thực tiễn diễn ngôn.

Khảo sát qua những công trình nghiên cứu về diễn ngôn, chúng tôi tạm kết lại rằng: Diễn ngôn đã trở thành khái niệm của khoa học liên ngành và khoa học đa ngành; một hiện tượng siêu văn bản, liên văn bản, liên văn hóa trong tính thống nhất, tính hệ thống, tính chỉnh thể. Diễn ngôn có rất nhiều. Nếu gắn với ý thức hệ xã hội thì có diễn ngôn tư sản, diễn ngôn vô sản, diễn ngôn Mácxit, diễn ngôn hiện đại, diễn ngôn hậu hiện đại. Nếu gắn với các lĩnh vực tri thức thì có diễn ngôn văn học, diễn ngôn vật lí, diễn ngôn thi ca. Nếu gắn với văn học thì có diễn ngôn tính dục, diễn ngôn lý luận phê bình, diễn ngôn phức điệu (đa âm, đa thanh), diễn ngôn các navan, diễn ngôn nghịch dị, diễn ngôn nữ quyền, diễn ngôn trần thuật, diễn ngôn tượng trưng, siêu thực, diễn ngôn thơ cổ, diễn ngôn thơ mới, diễn ngôn trần tục, diễn ngôn thi vị hoá, diễn ngôn văn học sử thi, diễn ngôn ám thị,... Nếu gắn với ngôn ngữ học thì có diễn ngôn thường nhật, diễn ngôn đàm thoại. Nếu gắn với các chủ nghĩa, trào lưu, khuynh hướng văn học thì có diễn ngôn chủ nghĩa cổ điển, diễn ngôn chủ nghĩa lãng mạn, diễn ngôn chủ nghĩa hiện thực. Nếu gắn với quan hệ kinh tế thị trường thì có: diễn ngôn tiếp thị, diễn ngôn bán hàng, diễn ngôn tiêu dùng, diễn ngôn chứng khoán. Ngoài ra còn có diễn ngôn thể chế hoá, diễn ngôn chính trị, diễn ngôn truyền thông, diễn ngôn văn hóa, diễn ngôn triết học, diễn ngôn điện ảnh, diễn ngôn đời tư - thế sự - nhân văn, diễn ngôn lịch sử - văn hóa,...

Vận dụng lý thuyết diễn ngôn vào nghiên cứu văn học, chúng tôi nhận thấy các nhà văn nữ sử dụng rất nhiều loại diễn ngôn trong quá trình sáng tác của mình: diễn ngôn trần thuật, diễn ngôn tính dục, diễn ngôn nữ quyền, diễn ngôn thân thể,... Chúng tôi gộp chung lại những diễn ngôn ấy là diễn ngôn giới. Diễn ngôn giới chính là lời nói, lời phát ngôn, là hành động lời nói của giới nữ tạo sinh văn bản gồm người nghe bình đẳng với người nói, là sự tương tác trong giao tiếp của phụ nữ với văn hoá xã hội. Diễn ngôn giới thư hai thể hiện tri thức, quyền lực, địa vị của phụ nữ đối với xã hội. Họ là những cá nhân có quyền được trải nghiệm, được yêu thương, được mưu cầu hạnh phúc, được nói lên tiếng nói của mình và được đứng ngang cùng với nam giới. Các nhà văn nữ Việt Nam tuy khác nhau về hoàn cảnh, địa vị, tính cách, tư tưởng, ước mơ, hoài bảo nhưng trên tất cả các trang viết của họ đều thể hiện tư tưởng nghệ thuật, quan điểm xã hội, tri thức và tài năng của mình. Họ đã dùng ngòi bút làm vũ khí sắc bén để đấu tranh cho sự bình đẳng giới của mình. Trong đó, chất nữ: vừa sâu sắc vừa nhẹ nhàng và đầy trải nghiệm luôn hiện diện trên từng trang viết của họ. Và, Y Ban cũng vậy.

\section{Hành trình đi tìm bản thể nũ}

Bằng diễn ngôn nữ giới, truyện ngắn Y Ban bộc lộ hết tất cả những khát khao thầm kín từ trong sâu tâm thức của người phụ nữ. Trong văn bản, những lời phát ngôn của các nhân vật như đại diện cho tiếng nói của giới thư hai, khẳng định nhân vị đàn bà. Một hành trình đi tìm bản thể trong họ cũng diễn biến đầy phức tạp: Vừa hiện sinh vừa phân tâm.

Họ là ai? Họ là "nàng" - người đàn bà không cầu kỳ và biết tự yêu mình như những người đàn bà khác. Nàng có một gương mặt rạng ngời với đôi mắt long lanh và một cánh môi luôn hé mở. Tim nàng đập tung lồng ngực, đập ran trong lồng ngực trước những dòng tin nhắn của $\mathrm{N}$. Nga. Nàng thèm khát được hôn cái môi dưới trễ tràng của $\mathrm{N}$. Nga. Chồng nàng - một người đầu ấp tay gối hằng đêm nhưng chẳng khi nào hôn nàng. "Nàng thành một người đàn bà luôn khao khát nụ hôn. Sự khát khao thành một nỗi ám ảnh. Khi nhìn một người đàn ông điểm đầu tiên và cuối cùng nàng nhìn là đôi môi”" (Em vẫn gọi tên anh là nước Nga). Và nàng thấy mình thật sự hạnh phúc và biết yêu khi những nụ hôn nồn nàn trao cùng $\mathrm{N}$. Nga "Tôi đang hạnh phúc. Tôi chưa khi nào được hạnh phúc như vậy. Bây giờ nàng có lý do để ra đi”" (Em vẫn gọi tên anh là nước Nga).

Họ là "em", là "chị" khát khao được sự nhẹ nhàng, nghệ thuật làm tình của chồng để cảm thấy được thân thể mình như bình thuỷ tinh dễ vỡ, cần lắm sự nhẹ nhàng và cần lắm được nâng niu. Họ là em khát khao được chồng thơm vào chỗ ấy cũng như đàn ông cần "Khi em còn ở với chồng, em chỉ muốn được một lần chồng yêu chồng dấu vào đấy thôi. Em mất công cắt tỉa cho gọn gàng, lại kỳ công đun thảo dược để ngâm cả bàn tọa vào như hướng dẫn của in-tơ-nét nhé. Tối đấy 
tìm mọi cách khéo léo để chồng thơm" (Cuối cùng thì đàn bà muốn gi).

Họ là "em" trong Hai mươi bảy bước chân là lên thiên đurờng - người con gái nhẹ dạ đã không thể vượt qua "cám dỗ ngọt ngào... để theo anh vào khách sạn với bước chân run rẩy". Sau cơn đê mê của cuộc tình mây mưa, sự thoả mãn của người phụ nữ thường biểu hiện rõ qua làn da "sáng loáng", đôi môi "đỏ mọng và trễ xuống", mắt "sáng long lanh". Nếu những hành vi ây được bào chữa bởi cái vô thức bản năng trỗi dậy thì không đúng. Bởi vì, "em là người con gái bình thường nhưng thông minh". Vì thông minh nên em biết chỗ đứng của mình trên trái đất này. Em luôn tự quyết định cuộc sống và tự trách nhiệm trước hành động của mình. Nhưng trong sâu thẳm của đáy lòng họ luôn khát khao một tiếng yêu thương từ người đàn ông mà họ đã dâng hiến cả trái tim lẫn thể xác. Em không phải là "một người đàn bà dễ dãi, hư hỏng" và "em cũng không sống luỵ người khác". (27 bước chân là lên thiên đường).

Hình ảnh những người phụ nữ trong truyện ngắn $\mathrm{Y}$ Ban sao quá đỗi hiện thực. Đó không còn là những hình ảnh lý tưởng, cao đẹp thủ tiết thờ chồng, vò võ một mình với chiếc bóng năm canh. Đứng trước văn bản, sự tiếp nhận của những độc giả khó tính, phong kiến sẽ khó lòng chấp nhận bởi hành vi ngoại tình trước việc chồng đối diện giữa sự sống và cái chết nơi chiến trường đầy ác liệt với bơm rơi lửa đạn. Về lý thuyết sinh học và lý thuyết về tâm thường cho rằng tình yêu và tình dục trong người phụ nữ luôn đi đôi với nhau. Lụa trong Chơ rằm duới gốc cây cổ thu yêu và khao khát được Thắng ôm ấp, được Thắng mơn man da thịt mình đến cả trong những giấc mơ mỗi đêm. Trong vòng tay ôm chặt của Thắng, Lụa có cảm giác như "da thịt mình tách ra". "Giấc mơ đêm lại đưa cô vào cơn mê lạ. Thắng nằm bên cạnh cô vuốt ve, bàn tay anh động đến đâu thì da thịt cô mở ra đến đó. Một luồng khí trời tinh khiết, một dòng nước nguồn tinh khiết, một tia chớp chói sáng bủa vây cơ thể Lụa. Cô nép vào người Thắng" (Chọ rằm duới gốc cây cổ thu).

Cuộc sống với bộn bề lo toan, người phụ nữ trong Cuới chơ với biết bao nhiêu hoài bão, với sự đè nén từ nhiều áp lực buộc con người ta phải lao mình học tập, nghiên cứu và làm việc để vươn đến danh vọng và tiền tài, để không bị "lạc lối” với xã hội. Nhưng trong góc lớn của con người, tình yêu không bao giờ nguội lạnh và bị dập tắt. Dù đâu đó, có những lúc, ai đó trơ ra với trước những hình ảnh lãng mạn, những việc làm đầy sự quan tâm của tình thương thì đó chỉ là những phút giây tạm thời bị công việc và stress bao phủ, che mờ. Chỉ khi được sống với chính mình, sự thèm khát yêu đương lại trở về bên họ.

Nhưng xét tới cùng bản thể con người, nhất là người phụ nữ, ở họ luôn cần hơi ấm, cần sự ôm ấp, ve vuốt, âu yếm mỗi ngày. Đàn ông và xã hội cần hiện sinh hơn để dễ dàng chấp nhận "cái lỗi lầm bình thường của sinh lý". Cái "đàn bà" của họ cũng cần được thoả mãn như đàn ông. Nếu quy chụp và đeo gông vào cổ thân phận đàn bà với những hủ tục phong kiến một thời, với khuôn mẫu "trai năm thê bảy thiếp, gái chính chuyên chỉ có một chồng" hay "nhịn đói chuyện nhỏ, thất tiết mới là chuyện lớn" thì những cô gái bán hoa, những người phụ nữ tự nguyện làm nhân tình cho người đàn ông đã có vợ, những người vợ ngoại tình trong lúc vắng chồng, những người phụ nữ lỡ bước vượt lối, ... sẽ khó trở về sống vui, sống tốt cho ngày mai. Có lẽ, $\mathrm{Y}$ Ban cũng không thể nào vượt ra khỏi văn hoá Phương Đông dù chị có những tiếng nói trải lòng cùng giới nữ.

Những người phụ nữ trong truyện ngắn của $\mathrm{Y}$ Ban đã dừng lại đúng với ngưỡng cho phép của xã hội. Sau bao nhiêu lần giằng xé giữa bản năng và ý thức, giữa văn hoá áp đặt và ham muốn, giữa khát khao với lý trí thì họ cũng quay về với chính phụ nữ Việt Nam: khát khao yêu thương, khát khao được tự do thoả mãn thân xác nhưng họ còn gia đình, còn vì con cái, vì phẩm giá được rèn đúc từ cội nguồn gốc rễ. Dù họ có được trao quyền tự do yêu thương như đàn ông, có quyền lựa chọn hành động của mình với người khác giới thì đàn bà vốn vẫn là đàn bà. Sau những lần tự cho mình được phép vượt qua những luân thường đạo lý thì tự họ mâu thuẫn với chính mình, tự dằn vặt lương tâm. Nhân vật thị trong truyện ngắn I am đàn bà hay bất kỳ nhân vật "nàng" trong truyện ngắn Sau chớp là giông bão hay nhân vật "em" trong truyện ngắn 27 bước chân là lên thiên đường,... họ đều rơi vào trạng thái như nhau khi tự họ nhận thức ra những hành động của mình trái với đạo đức của người phụ nữ Phương Đông.

Người phụ nữ sợ phần ít những bài giảng "lên lớp đạo đức và xót thương" của những người cùng giới, những người cùng cảnh ngộ. Tôi trong Con quỷ nhỏ trong tôi, khát khao thổ lộ với ai đó để san sẻ nỗi lòng. Nhưng họ biết rằng "dù ai đó có hoàn cảnh tương tự như tôi thì cũng sẽ lên lớp đạo đức và xót thương tôi". Nhưng cái họ sợ nhất là phải đối mặt với chính người ấy. Sự "khinh miệt" xem họ như là "những cô gái tầm thường nhất với những cám dỗ tầm thường”. Đàn bà sợ bị coi khinh. Lòng tự trọng đàn bà cao như ngọn núi nhưng sự nhẹ dạ, yếu lòng cũng rộng như biển khơi. Để 
rồi giữa cái mạnh và cái yếu luôn mâu thuẫn nhau trong một con người, dù họ có lý trí, có khôn ngoan ây, nhưng phụ nữ vẫn luôn cả tin.

Biết rằng số phận người đàn bà quá mong manh, đủ điều nước mắt và tiếng khóc nhiều về đêm, trong sự cô đơn và trống vắng, nhưng họ là "nàng" vẫn khát khao một bờ vai để tựa, một lồng ngực nồng ấm để rúc đầu mà khóc rấm rứt cho vơi đi nỗi tủi thân. Và biết người ta đã có vợ nhưng trong "Không gian vắng lặng như tờ, nàng quay ý nghĩ về với anh. Nàng thèm muốn có anh ngay bên cạnh lúc này. Nàng sẽ rúc đầu vào ngực anh khóc rấm rứt. Khóc cho vơi đi sự tủi thân. Khóc cho vơi đi sự tủi hờn. Anh sẽ ôm chặt nàng và xoa vào lưng nàng. Hoặc lúc thảnh thơi không âu yếm nhau anh nằm phía sau lưng nàng hít hà phía sau lưng cái mùi của nàng... Sự khao khát làm nàng rơi vào ảo giác... anh chầm chậm đến bên nàng. Anh ngồi xuống bên nàng, cúi xuống ôm lấy nàng" (Nhân tình). "Cảm xúc khát thèm đang ngủ im bật dậy" đã làm thị trong I am đàn bà phải "nằm mộng có một người đàn ông hôn thị" và nhớ rõ mồn một về một giấc mơ mà thị "đã nắm chặt lấy con giống con má để đưa nó vào người thị”. Sau cơn mơ, thị tỉnh giấc trong ngất ngây của sự khát thèm. “Thị nằm mộng có một người đàn ông hôn thị khiến cho cảm xúc khát thèm của thị đang ngủ im bật dậy. Thị nhớ rõ mồn một giấc mơ tối qua là thị đã nắm chặt lấy con giống con má để đưa nó vào người thị mà không được. Thị tỉnh giấc trong ngây ngất của sự khát thèm" (I am đàn bà).

Diễn ngôn trong truyện ngắn $\mathrm{Y}$ Ban được biểu đạt qua những lời nói, những suy nghĩ, những tâm tư giãi bày của từng nhân vật nữ. Dù mang hơi hướng khác nhau nhưng ở họ vẫn luôn giằng co giữa lý trí và tình cảm, giữa "tam tòng tứ đức" ngày xưa và lối sống hiện đại ngày nay, giữa lý trí và ham muốn. Trong hành trình đi tìm bản thể, hướng đến những khát khao yêu đương, những ham muốn bản năng đời thường thì họ phải trả giá bằng nhiều cảnh trớ trêu và nỗi cay đắng. Thị ( $\mathrm{I} \mathrm{am}$ đàn bà) bị vợ ông chủ đánh ghen và giải ra toà "bà chủ vừa khóc vừa hét lên be be và đấm đá thị túi bụi”. Nàng (27 buớc chân lên thiên đường) nhận lấy những lời lạnh lùng không chút tình cảm sau lần ân ái "Vào một thời gian thích hợp nào đó chúng mình sẽ gặp nhau nữa nhé. À này em, tình cờ mình gặp ở đám đông chúng mình nên tế nhị nhé" (27 buớc chân lên thiên đường). Miên (Mỗi ngườ đàn ông chỉ của riêng một người đàn bà) đã qua nhiều người đàn ông nhưng vẫn chưa có được người đàn ông của riêng mình. "Nàng" (Nhân tình) một mình đối diện với tử thần, đối diện với cái bóng đèn đỏ nhìn chòng chọc vào mắt chị giễu cợt.

Hành trình đi tìm bản thể nữ là một hành trình đầy cay đắng bởi sự dấn thân vào cuộc đời của phụ nữ. Văn hoá Phương Đông vẫn không thể chấp nhận những lối sống hiện đại Phương Tây, những suy nghĩ và hành động táo bạo vượt ngưỡng cho phép. Dù Y Ban ra sức vẫy vùng với những "móng vuốt" nữ để chứng tỏ bản thể đàn bà nhưng Y Ban cũng quay trở về lối đạo đức xưa. Đạo đức Nho giáo phong kiến có bị mai một nhưng nó không mất đi mà chỉ biến đổi kiểu dáng với muôn hình vạn trạng. Dù cho xã hội có tiến bộ, dù cho văn hoá Tây Đông có giao lưu, ảnh hưởng nhưng có lẽ vẫn không thể thay đổi suy nghĩ của đàn ông Phương Đông về một người phụ nữ. Họ có thật sự được quyền lựa chọn hạnh phúc, có thực sự được tự do trong hành vi ứng xử của mình theo lối sống Tây, có thực sự được trân trọng trong mắt những người đàn ông họ đã dâng hiến cả trái tim và thể xác.

\section{Khẳng định bản thể nữ}

Nếu phụ nữ muốn bình đẳng về thân xác, tình dục lẫn tinh thần với nam giới thì "người nữ phải được tiếp cận với thế giới nam giống như người nam tiếp cận với thế giới nữ" (Simone de Beauvoir). Chẳng thể nào có được kinh nghiệm hữu ích với những dòng lý thuyết trên sách vở. Dấn thân, từng trải thì mới hiểu được có bao nhiêu người đàn ông và người phụ nữ trên thế gian này. Bằng diễn ngôn nữ giới, $\mathrm{Y}$ Ban đã mớm cho những nhân vật nữ của mình trải nghiệm từng nỗi đau khi bị bỏ rơi sau bao nhiêu sự yêu thương và hi sinh ( $A i$ chọn giùm tôi), nỗi đau bị coi khinh ( $A i$ chọn giùm tôi, Cõi hận thù), nỗi cô đơn khi không có chồng bên cạnh (I am đàn bà, Bây giờ con mói hiểu), nỗi nhục nhã của những cô bán hoa, nỗi ê chề của kẻ nhân tình với người đàn ông đã có vợ (Nhân tình), nỗi lo lắng khi không thắng ham muốn để rơi vào cạm bẫy tình yêu (27 buớc chân là lên thiên đường), hi sinh tuổi xuân của mình ở bên cạnh người đàn ông cả đời chỉ biết cống hiến cho nghệ thuật (Tôi và anh).

Thị trong $I$ am đàn bà luôn trói mình trong những dòng suy nghĩ mông lung, thị chửi rửa bản thân, thị thấy mình xấu xa, đồi bại. Thị ân hận, càng tỉnh mộng, sau cơn trỗi dậy điên cuồng của bản năng thị càng sợ hãi, càng đau đớn cho thân mình. Thị cô đơn nơi đất khách quê người, thị quá khát khao được trút bầu tâm sự. Thị muốn thanh minh cho hành vi của mình. Nhưng sau tất cả những nỗi niềm sâu kín của thị chỉ vì thị là đàn bà - đàn bà nghèo, xa quê. Và sau bao suy tư, suy nghĩ hay sau bao sự hổ thẹn, hối hận bản thân 
về hành vi đồi bại của mình thì thị thật sự đã vượt lên trên mọi áp chế về luân lý tam tòng tứ đức của phụ nữ ngày xưa để khẳng định nhân vị đàn bà, khẳng định bản thể đàn bà. "Thị muốn nói thật to trước toà một câu nói mà mọi người đều có thể hiểu. Thị cố nhớ lại cái câu tiếng Anh cô giáo đã dạy cho thị trước khi ra nước ngoài: I am: Tôi là. I am: Tôi là. I am Đàn bà. Đúng rồi I am đàn bà, thị sẽ nói câu đó thật to trước toà" (I am đàn bà). Chính câu nói của thị "I am: Tôi là. I am: Tôi là. I am đàn bà” là tiếng nói xót xa, mạnh mẽ chống lại những định kiến của xã hội về phụ nữ; là tiếng nói khát khao yêu thương, chia sẽ, được sống đúng với những bản năng sống vốn có của mình.

Phụ nữ hiện đại luôn nhận thấy giá trị bản thân. Họ là những người phụ nữ thông minh và học giỏi. Phụ nữ hiện đại luôn làm chủ mọi tình thế. Mười bảy tuổi đủ để khẳng định bản thân, tài năng và sắc đẹp. Khẳng định vẻ đẹp thân thể cũng là khẳng định quyền nữ giới của mình. Nguời đàn bà đứng trước gương luôn tự tin, kiêu hãnh với sắc đẹp của mình, "nhẹ nhõm, nàng chạy ra đứng trước gương. Một chiếc gương to soi rõ từ đầu đến chân mà bao nhiêu lần nàng đã soi vào đó. Tấm gương trả lại cho nàng một người đàn bà có da thịt, gương mặt đầy đặn và không còn trẻ nữa... đôi mắt mở to, da mịn màng, cái miệng tươi của nụ cười vừa phải... tuy hơi đẫy đà những vẫn còn eo" (Nguời đàn bà đíng trước guoong). Nàng đỡ nguyên quần áo, gỡ chiếc gương lại chỗ nắng để chiêm ngưỡng nét trẻ trung của chính ta. Nắng tô hồng và làm rạng rỡ thêm khuôn mặt "bầu bầu trẻ lâu".

Tự quyết định hôn nhân của mình, là người chủ động ngõ lời yêu, chủ động cầu hôn và sã̃n sàng chia tay "anh có muốn cưới em làm vợ không?... Cảm ơn anh đã nói sự thật. Nào chúng ta chia tay”. Hồng nhan bạc phận hay hồng nhan bạc triệu hay hồng nhan luôn gian truân, trai tài, gái sắc, phụ nữ ngày nay không những đẹp mà còn chứng tỏ mình bằng sự thông minh và sự mạnh mẽ. Tâm lý nam giới bây giờ cũng không đón nhận một chiều về nét đẹp đơn thuần của phụ nữ. Nội tâm, cá tính và sự tự tôn, sự kiêu hãnh là những yếu tố tạo nên sự hoàn thiện ở một người phụ nữ. Họ cần phải đẹp về thể xác, đẹp về tâm hồn và đẹp cả đạo đức.

Khi phụ nữ đã có tài, có tiền và có danh vọng thì họ có quyền tự do và bình đẳng. Theo Chủ nghĩa Marx, chỉ khi lao động, con người mới được tồn tại. "Người phụ nữ có thể tự tạo công việc cho mình là người phụ nữ sẽ có được danh vọng và vận mệnh" (Amelia Earhart). Phụ nữ muốn tự giải phóng mình thoát khỏi sự phụ thuộc vào nam giới, khẳng định vị thế của mình với đàn ông và trong xã hội, làm chủ được đồng tiền, làm chủ cuộc sống của mình,... thì chỉ có lao động sản xuất mới có thể thực hiện được bình đẳng giới.

Phụ nữ bây giờ có quyền được nạo phá thai. Nhưng giữa quyền được tự do quyết định cuộc sống và lương tâm của người mẹ, trong sự đau đớn khi chối bỏ thể xác, chối bỏ linh hồn bé nhỏ, họ nhận ra rằng: Sau ngày ấy tình yêu của họ đã chết đi theo sinh linh tội nghiệp. Sau ngày ấy, "con đã là người đàn bà từng trải”, nhưng bên ngoài họ vẫn là một thiếu nữ trong sáng, e ấp, con chờ một tình yêu mới đến (Búc thu gởi $m e \hat{A} u(O)$ ). Họ là những người mẹ quá trẻ có cơ hội làm lại cuộc đời của mình. Truyện ngắn Búc thu gởi $m e \hat{A} u C o$ của $\mathrm{Y}$ Ban vừa nêu lên vấn nạn phá thai hiện nay rất nhiều ở giới trẻ nhưng đồng thời những lời diễn ngôn ấy như những lời đòi bình quyền trong sự tự do mưu cầu hạnh phúc cá nhân của phụ nữ. Họ có quyền được chọn lựa có con hay không có con với những người đàn ông mà họ yêu.

Họ tự tin và ranh mãnh như "con quỹ nhỏ". Họ mạnh dạn thổ lộ những suy nghĩ của mình với người khác. Có khi ngạo mạn và thật trẻ con. Phụ nữ ngày nay cần sống cho mình. Yêu mình trước hãy yêu người sau. Người phụ nữ có biết quý trọng bản thân mình thì mới được người đàn ông trân trọng. Cuối cùng người đàn bà cần là gì? "À, thì chỉ cần thỏa ý thích của mình thôi. Chị ý à, chị yêu mình hơn tất cả, nên chị phải tự mình cảm nhận được sự êm ái của cái quần ôm sát vào mình, cái áo mềm ấm trên ngực mình. Chị cần gì phải mặc bộ đồ lót để vừa mắt ai đâu. Đàn bà trên đời này rất là ngu, luôn luôn tìm mọi cách để làm vừa mắt một thằng đàn ông nào đấy. Mà chị nói cho em biết, đàn ông là một thằng thượng đế mắt đầy dử nhá, có khi đã bị kéo màng. Thế thì nó làm sao mà nhìn ra vẻ đẹp thật sự của đàn bà?". (Cuối cùng thì đàn bà muốn gì).

Mỗi phụ nữ trên khắp địa cầu này, không phân biệt màu da, không phân biệt sắc tộc, không phân biệt Phương Tây hay Phương Đông, ở họ luôn có điểm chung: Khát khao được yêu thương, khát khao được hạnh phúc, được trân trọng và khát khao được bình đẳng, bình quyền từ thể xác, tinh thần đến tình dục. Trong cuộc đời phụ nữ của mình, họ luôn cố gắng vươn lên để khẳng định bản ngã, khẳng định vị thế của mình đối với nam giới trên mọi phương diện. Mục đích của nữ quyền như một phong trào chính trị là làm cho đàn bà và đàn ông bình đẳng hơn về pháp lí, xã hội, tình dục và văn hoá. Y Ban được xem là nhà văn tiêu biểu, góp thêm tiếng nói mạnh mẽ, quyết liệt và góc cạnh với xã 
hội, nhất là với cánh đàn ông, về những nỗi niềm chung, những suy tư chung, những khát khao chung ấy của phụ nữ.

\section{Niềm kiêu hãnh nữ giới}

Văn học của $Y$ Ban từ lâu đã được các nhà nghiên cứu xếp vào dòng văn học nữ quyền. Với những tác phẩm của Y Ban, người ta luôn thấy thấp thoáng hình ảnh của chính chị trong những hình tượng người phụ nữ. Sáng tác, với nhiều nhà văn nữ, đồng nghĩa với một cuộc kiếm tìm: đi tìm bản thể của mình, kể những câu chuyện về giới mình, cất lên tiếng nói của mình.

Y Ban cũng vậy. Trong cuộc đi tìm mình và những khả tính của giới mình, chị đã bám vào cái cốt tự nhiên nhất của người nữ. Bản thể nữ, với $Y$ Ban có lẽ là cái tự nhiên này. Bản thể nữ không chỉ là phần tự nhiên ở con người, mà phần tự nhiên đó được hòa kết với yếu tố xã hội cụ thể; nó không phải người nữ muôn thuở mà là người nữ trong thời điểm hiện tại của quá trình lịch sử, thích ứng với những vận động của đời sống nhân loại.

Ngòi bút của $Y$ Ban luôn thể hiện rõ ràng cái bản thể nữ trong từng câu chuyện, trước hết là cái nhìn sâu hơn vào bản năng của giới. Chính vì thế mà chị diễn tả bản năng tính dục ở người đàn bà đậm đặc đến mức có những tác phẩm của chị từng bị coi là dâm thư. Nhưng còn có một thứ bản năng nữa ở người phụ nữ mà $Y$ Ban diễn tả với tất cả sự thấu hiểu cũng như niềm kiêu hãnh của đàn bà - bản năng sinh tồn. Vượt lên trên vấn đề dục tính, Y Ban hướng đến chức năng thiêng liêng của người đàn bà, đó là sự sinh nở, "có một thứ tồn tại trong cơ thể người đàn bà làm thế giới phẳng từ khi xuất hiện loài người. Đó là cái dạ con. Mọi hạt giống gieo vào cái dạ con đàn bà đều có thể nảy mầm. Một khi hạt giống đã nảy mầm rồi thì mọi sự khác biệt đều được dàn phẳng $\mathrm{ra"} \mathrm{(Em} \mathrm{vẫn} \mathrm{gọi} \mathrm{tên} \mathrm{anh} \mathrm{là} \mathrm{nuớc} \mathrm{Nga).} \mathrm{Nhiều}$ nhân vật của Y Ban thể hiện bản tính làm mẹ (Ngươi đàn bà có ma lục, Bức thư gửi me Âu Cơ....), khát vọng được sinh con (Nhũng nghịch lí của thần Airet, Xuân Tù Chiều). Trong truyện ngắn của Y Ban ngòi bút của Y Ban nói về giới, về bản thể nữ theo cách sắc sảo, táo bạo. Chị thường viết về bản thể nữ thông qua hình ảnh người mẹ, một hình ảnh thiêng liêng nhất của người phụ nữ. Người mẹ ở đây nổi bật tình thương yêu, tận tụy, chịu đựng, bao dung, và nước mắt. Là người phụ nữ luôn cầu mong sự bình yên trong cuộc sống gia đình.

Những nhân vật nữ của $Y$ Ban luôn khao khát được yêu, được sống, được là chính bản thân mình. Vì lẽ đó mà nhân vật của chị thường hiện lên với đầy vẻ nữ tính: từ làn da, mái tóc, đôi mắt, từ tấm lưng, bắp tay, bắp chân, bầu ngực... Y Ban thường miêu tả cơ thể, những biểu hiện riêng có của cơ thể nữ, khí chất nữ, những biểu hiện sinh học nữ... mang ký hiệu thân thể. Đó là làn da vỡ ra trắng nõn, mái tóc đã vào cữ óng của cô bé mới lớn trong tác phẩm Chọ rằm duới gốc cây cổ thu (2003), từ cái bắp chân to như cây chuối hột, bàn tay to như cái quạt nan, nước da nâu rám, hàm răng hạt na đều tăm tắp của người đàn bà nghèo khổ trong I'm đàn bà (2006). Hay trong truyện Người đàn bà đứng trước gương thể hiện sự khám phá lại cơ thể của người đàn bà đã qua sinh nở, có cái nghi ngại, ngỡ ngàng, có cả lo lắng, sợ hãi, có cả sự tự hào, tự ngưỡng mộ. "Nàng chậm rãi mở từng cúc áo, khuôn ngực đầy đặn, trắng ngà hiện ra. Hai tòa thiên nhiên như hai nắm cơm đẹp, chắc chắn với những núm hoa bí, hoa mướp đã qua thời kì đơm trái" (Người đàn bà đí̛ng truớc gương)

Những nhân vật nữ của $\mathrm{Y}$ Ban thường là những nhân vật nữ có trí thức, nên có những mối quan hệ rộng rãi do công việc mang lại. Chẳng hạn như: nhân vật "nàng" trong truyện ngắn Sau chớp là giông bão - có công việc văn phòng ổn định, gia đình yên ổn và người chồng thương yêu mình. Chị đẹp, một cái đẹp rất đỗi đàn bà, làm say mê những người đàn ông khác ngoài chồng mình. Ở nhân vật này, Y Ban cho toát lên sự quyến rũ của một người phụ nữ có cuộc sống viên mãn, ở thời điểm đằm thắm nhất của đời người. Nhìn chung, những nhân vật đàn bà trong văn của chị hiện lên với đầy đủ nét "thiên tính nữ": Bản tính dịu dàng, ưa sự nhẹ nhàng, tinh tế; bản năng sống, bản năng yêu, bản năng tính dục, bản năng làm mẹ... Tất cả đều được thể hiện rất tự nhiên, sinh động với cái nhìn vừa quen thuộc, vừa mới lạ, gần truyền thống đấy nhưng cũng hết sức tân thời, hiện đại.

Người đàn bà trong văn Y Ban thường rất tự tin phô bày vẻ đẹp hình thể và sức hấp dẫn giới tính. Ở nhiều truyện ngắn: Ngườ đàn bà có ma lưc, Tự, Gà áp bóng, Người đàn bà đứng truớc guoong, Cuộc tình silicôn..., những nhân vật nữ luôn có sở thích ngắm mình khỏa thân trước gương để nhận ra những nét đẹp quyến rũ của cơ thể, để tự hào về vẻ đẹp trời phú của mình. Với họ, một cơ thể đẹp, một nét duyên ngầm chính là sức mạnh, là niềm kiêu hãnh, tự tin để bước vào cuộc sống, nhất là trong những cuộc chinh phục thế giới đàn ông.

Không chỉ về hình thể bên ngoài, người phụ nữ còn rất tự tin về tài năng và trình độ hiểu biết, đó cũng là một phương diện để họ xác lập vị trí chủ thể của mình trong xã hội: chủ thể về tư duy, nhận thức độc lập và linh hoạt. Sống trong thời đại mới, họ là những người có trình độ học vấn đáng nể trọng. Người đàn bà trong 
Tự, Cưới chọ hay Xuân trong Xuân Tù Chiều là những tiến sĩ khoa học đi tu nghiệp ở nước ngoài; những người đàn bà tật nguyền như Nấm (Đàn bà xấu thì không có quà), người đàn bà (Đứa con và người đàn bà tàn tật) cũng tự tạo vị thế cho mình qua nỗ lực tốt nghiệp đại học, và hầu hết những cô gái trẻ trong văn $\mathrm{Y}$ Ban đều là những cô sinh viên nhiều ước mơ, hoài bão.

Tất cả họ, bằng nghị lực, ý thức cầu tiến và bản lĩnh sống mạnh mẽ đã làm được những điều mà đối với người phụ nữ Việt Nam trước đây, đó chỉ là mơ ước. Trong nhiều hoạt động chuyên môn, xã hội, những nhân vật nữ của $\mathrm{Y}$ Ban còn biểu hiện những năng lực thực sự. Dù tài năng đến từ những điều bình thường như một giọng hát hay, sự khéo léo hơn người hay những phẩm chất quan trọng khác, thì mọi biểu hiện tài năng ở họ đều mang lại hiệu quả và được mọi người công nhận. Người phụ nữ với năng khiếu thiên bẩm về văn chương và sự thông minh đột khởi cũng được $\mathrm{Y}$ Ban chú ý miêu tả như chứng thực cho sự xâm lấn của phụ nữ vào những lãnh địa mà trước đây chỉ dành cho nam giới.

\section{Kết luận}

Để khẳng định vị thế của mình trong xã hội cũng như trong sáng tác văn chương, người phụ nữ đã trải qua bao nỗi đau và sự đắng cay. Đó là, cuộc tự vật lộn tranh đấu giữa lý trí và dục vọng, giữa nên và không nên, giữa nay và xưa ngay trong chính bản thân họ. Những lời văn mạnh mẽ đầy táo bạo của Y Ban đã thể hiện khát vọng phá vỡ tư tưởng khép kín về phụ nữ của xã hội nam quyền, phá vỡ toàn bộ hệ thống quan niệm lấy dương vật làm trung tâm, phá vỡ hệ thống cấu trúc phụ quyền, phá vỡ cấu trúc nhị phân đối lập. Bằng diễn ngôn nữ giới, Y Ban như đại diện "giới thứ hai” để lên tiếng nói đòi quyền bình đẳng giới với cánh mày râu, khẳng định nhân vị đàn bà, khẳng định nữ quyền, khẳng định quyền được sống và viết.

\section{TÀI LIỆU THAM KHẢO}

1. Bakhtin (1996), Chủ nghĩa Mác và triết học ngôn ngữ, Nxb Giáo dục Hà Bắc, Thạch Gia Trang.

2. Bakhtin (1998), Bakhtin toàn tập, tập 2, Nxb Giáo dục Hà bắc, Thạch Gia Trang.

3. Bakhtin (1993), Nhũng vấn đề thi pháp Dostoiépxki, Nxb Giáo dục, Hà Nội.

4. Y Ban (2006), I am đàn bà, Nxb Phụ Nữ, Hà Nội.

5. Y Ban (2008), Xuân Tù Chiều, Nxb Phụ Nữ, Hà Nội.

6. Y Ban (2012), Trò chơi huỷ diệt cảm xúc, Nxb Trẻ, TP. HCM.
7. Y Ban (2014), Sống ở đời biết khi nào ta khôn, Nxb Văn học, Hà Nội.

8. Y Ban (2014), Người đàn bà và nhũng giấc mo, Nxb Thời đại, Hà Nội.

9. Y Ban (2014), Người đàn bà xấu thì không có quà, Nxb Văn học, Hà Nội.

10. Y Ban (2014), $A B C D$, Nxb Trẻ, Hà Nội.

11. Y Ban (2015), Cuối cùng thì đàn bà muốn gì, Nxb Phụ Nữ, Hà Nội.

12. V.I. Chiupa (2013), Diễn ngôn nhu môt pham trù của tu tù hoc và thi pháp hoc hiện đại, truy cập ngày 08/04/2013, https://phebinhvanhoc.com.vn/dienngon-nhu-mot-pham-tru-cua-tu-tu-hoc-va-thi-phaphoc-hien-dai/.

13. V.I. Chiupa, Lã Nguyên dịch (2013), Trần thuật hoc nhu là khoa học phân tích diễn ngôn trần thuật, truy cập ngày 13/9/ 2013, http://www.hcmup.edu.vn/index.php?option=com cont ent\&id=14838\&tmpl=component\&task=preview\&lang $=$ vi\&site $=142$.

14. Foucault M (1998), Khảo cổ học tri thức, Nxb Tam liờn, Thượng Hải.

15. O.Frusakova (2013), Các lý thuyêt diễn ngôn hiện đại: kinh nghiệm phân loại, Truy cập ngày 22/3/2013, http://www.vanhoanghean.com.vn/chuyenmuc-goc-nhin-van-hoa/nhung-goc-nhin-van-hoa/cac-lythuyet-dien-ngon-hien-dai-kinh-nghiem-phan-loai.

16. Vashili Gorelov (2014), Phân tích diễn ngôn trong li thuyết xã hội học: Michel Foucault và Teun Adrianus Van Dijk, truy cập ngày 09/05/2014, http://nguvan.hnue.edu.vn/Nghiencuu/Lyluanvanhoc/ta bid/104/newstab/298/Default.aspx

17. Trần Ngọc Hiếu (2016), Trò chơi diễn ngôn trong lý thuyết văn học hậu hiện đại, tạp chí Văn học Đại học Văn hiến, Số 11, tháng 11/2016.

18. Nguyễn Văn Hùng (2016), Nhũng hình thái diễn ngôn mới trong tiểu thuyết lịch sủ Việt Nam sau đổi mói, truy cập ngày 26/04/2016, http://tapchisonghuong.com.vn/tap-

chi/c349/n22986/Nhung-hinh-thai-dien-ngon-moitrong-tieu-thuyet-lich-su-Viet-Nam-sau-doi-moi.html.

19. Bernard Hurault \& Louis Hurault (2006), Kinh Thánh, Kinh Cưu ước và Tân vớc, Nxb Tôn Giáo, Hà Nội.

20. Trần Thiện Khanh (2010), Buớc đầu nhân diện diễn ngôn, diê̂n ngôn văn hoc, diễn ngôn tho (bài 1), truy cập ngày 11/10/2010, 
https://ngnnghc.wordpress.com/tag/phanlo\%E1\%BA\%A1i-di\%E1\%BB\%85n-ngon/.

21. IU. M. Lotman (2007), Cấu trúc văn bản nghệ thuật, Trần Ngọc Vương, Trịnh Bá Đĩnh \& Nguyễn Thu Thuỷ dịch, hiệu đính: Trần Ngọc Vương, Nxb Đại học Quốc gia Hà Nội, Hà Nội.

22. Sara Mills (2016), Các cấu trúc diễn ngôn, truy cập ngày 09/05/2014, http://khoavan.dhsptn.edu.vn/415 Cac-cau-truc-dienngon.html.

23. Jean - Paul Sarte (2016), Thuyết hiện sinh là một thuyết nhân bản, Nxb Tri Thức, Hà Nội.

24. Trần Huyền Sâm (2016), Nũ quyền luận ở Pháp và tiểu thuyết nũ Việt Nam đưong đại, Nxb Phụ Nữ, Hà Nội.

25. Trần Huyền Sâm (2016), Tiểu thuyết Phuơng tây hiện đại và các huoóng tiếp cận, Nxb Văn học, Hà Nội.

26. Trần Đình Sử (2013), Khái niệm diễn ngôn trong nghiên cúu văn hoc hôm nay. truy cập ngày 5 tháng 3 năm 2013, http://phebinhvanhoc.com.vn/khainiem-dien-ngon-trong-nghien-cuu-van-hoc-hom-nay/.

27. Trần Đình Sử (2013), Bản chất xã hội, thẩm mĩ của diễn ngôn văn học, truy cập ngày 23/5/2013, http://nguvan.hnue.edu.vn/Nghiencuu/Lyluanvanhoc/ta bid/104/newstab/104/Default.aspx.

28. Trần Đình Sử (2015), Khái niệm diến ngôn, truy cập ngày 4/1/2015, https://trandinhsu.wordpress.com/2015/01/04/khainiem-dien-ngon/.

29. Phùng Gia Thế - Trần Thiện Khanh (2016), Văn hoc và giới nũu, Nxb Thế Giới, Hà Nội.

30. Bùi Thị Tĩnh (2010), Phu nũ và giới. Nxb Chính Trị Quốc Gia, Hà Nội.

31. Liễu Trương (2011), Phân tâm học và phê bình văn hoc, Nxb Phụ Nữ, Hà Nội.

32. Viện Nghiên cúu Xã hội, Kinh tế và Môi truờng (iSEE) (2014), Diễn ngôn giới và tính dục trong cuộc sống muôn màu, Nxb Tri Thức, Hà Nội.

\section{Discourse of the second person showing through some typical short stories of Y Ban writer}

Truong Thi Thu Thanh

Article info

Recieved:

$21 / 10 / 2018$

Accepted:

10/12/2019

Keywords:

Y Ban; Woman;

Discourse theory;

Psychoanalysis;

Existential philosophy.

\begin{abstract}
Images of women in all classes, associated with many different lives, are not new in Vietnamese literature; but exploring the issues related to women in terms of discourse is a new direction in literary research. In this article, we focus on Y Ban's some typical short stories that writing about women who long for happiness, love, meeting their instinctive needs. They are always on a journey to find the essence, and since then they find the importance of the women, they try to rise to affirm women's status, assert their gender equality.
\end{abstract}

